\title{
Interactions between leaf water potential, stomatal conductance and abscisic acid content of orange trees submitted to drought stress
}

\author{
Mara de Menezes de Assis Gomes ${ }^{1}$, Ana Maria Magalhães Andrade Lagôa ${ }^{2}$, Camilo Lázaro Medina ${ }^{2}$, Eduardo \\ Caruso Machado ${ }^{2}$ and Marcos Antônio Machado ${ }^{3}$
}

\begin{abstract}
${ }^{1}$ Universidade Estadual do Norte Fluminense Darcy Ribeiro, Setor de Fisiologia Vegetal/LMGV/CCTA, CEP 28013-602, Campos dos

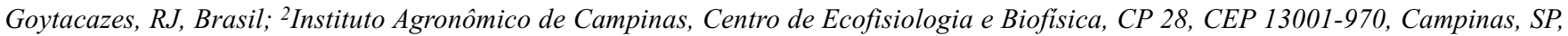
Brasil; ${ }^{3}$ Centro Avançado de Pesquisa Tecnológica do Agronegócio de Citros - "Sylvio Moreira", Instituto Agronômico de Campinas, Cordeirópolis, SP, Brasil.*Corresponding author: maramag@uenf.br

Received: 19/10/2004, Accepted: 20/11/2004
\end{abstract}

Thirty-month-old 'Pêra' orange trees grafted on 'Rangpur' lemon trees grown in $100 \mathrm{~L}$ pots were submitted to water stress by the suspension of irrigation. $\mathrm{CO}_{2}$ assimilation $(A)$, transpiration $(E)$ and stomatal conductance $\left(g_{s}\right)$ values declined from the seventh day of stress, although the leaf water potential at 6:00 a.m. $\left(\Psi_{p d}\right)$ and at 2:00 p.m. $\left(\Psi_{2}\right)$ began to decline from the fifth day of water deficiency. The $\mathrm{CO}_{2}$ intercellular concentration $\left(C_{i}\right)$ of water-stressed plants increased from the seventh day, reaching a maximum concentration on the day of most severe stress. The carboxylation efficiency, as revealed by the ratio $\mathrm{A} /$ $C_{i}$ was low on this day and did not show the same values of non-stressed plants even after ten days of rewatering. After five days of rewatering only $\Psi_{p d}$ and $\Psi_{2}$ were similar to control plants while $A, E$ and $g_{s}$ were still different. When $\Psi_{2}$ decreases, there was a trend for increasing abscisic acid (ABA) concentration in the leaves. Similarly, stomatal conductance was found to decrease as a function of decreasing $\Psi_{2}$. ABA accumulation and stomatal closure occurred when $\Psi_{2}$ was lower than $-1.0 \mathrm{MPa}$. Water stress in 'Pera' orange trees increased abscisic acid content with consequent stomatal closure and decreased $\Psi_{2}$ values. Key words: abscisic acid, Citrus sinensis, gas exchanges, water stress.

Interações entre potencial da água na folha, condutância estomática e conteúdo de ácido abscísico em laranjeiras submetidas a estresse hídrico: Laranjeiras 'Pêra' de dois anos e meio de idade enxertadas em limoeiros 'Cravo' foram cultivadas em vasos de 100 L com solo e submetidas ao estresse hídrico, pela suspensão da irrigação. Valores de assimilação de $\mathrm{CO}_{2}(A)$, transpiração $(E)$ e condutância estomática $\left(g_{s}\right)$ começaram a declinar a partir do sétimo dia de estresse, embora o potencial da água na folha às 6 a.m. $\left(\Psi_{p d}\right)$ e às 2 p.m. $\left(\Psi_{2}\right)$ começaram a declinar a partir do quinto dia de deficiência hídrica. A concentração interna de $\mathrm{CO}_{2}\left(C_{i}\right)$ das plantas estressadas aumentou a partir do mesmo dia, atingindo uma concentração máxima no dia de estresse mais severo. Assim, a eficiência de carboxilação dessas plantas, verificada pela relação $A / C_{i}$ foi menor nesse dia, não ocorrendo recuperação dessa razão mesmo dez dias após a reidratação. Até o quinto dia após a reirrigação, somente o $\Psi_{p d}$ e o $\Psi_{2}$ se recuperaram, sendo semelhantes aos das plantas controle. Quando o potencial da água na folha diminuiu, ocorreu uma tendência de aumento da concentração de ácido abscísico (ABA) nas folhas; da mesma forma, foi possível verificar que a condutância estomática diminuiu em função do decréscimo em $\Psi_{2}$. O acúmulo de ABA e o fechamento estomático ocorreram quando $\Psi_{2}$ foi menor que-1.0 MPa. A deficiência hídrica em laranjeiras 'Pêra' aumentou o conteúdo de ABA, com conseqüente fechamento estomático e decréscimo em $\Psi_{2}$.

Palavras-chave: ácido abscísico, Citrus sinensis, estresse hídrico, trogas gasosas. 


\section{INTRODUCTION}

Water stress affects several aspects of plant physiology, such as gas exchanges, hormone relations and mainly water relations. Citrus trees grow best in warm climates with moist but well-drained soils that typically have low water holding capacity (Syvertsen, 1999). Decreases in stomatal conductance values $\left(g_{S}\right), \mathrm{CO}_{2}$ assimilation values $(A)$ and growth rate are some of the indicators of water stress in citrus trees (Marler and Davies, 1988; Davies and Bower, 1994; Medina and Machado, 1998; Medina et al., 1998; Medina et al., 1999; Machado et al. 1999). Furthermore, in young lemon trees submitted to water stress the maximum daily trunk diameter decreases followed by a decline in sap flow (Ortuño et al., 2004). In orange trees, prolonged or excessive water stress can cause the fall of leaves, progressive drying of the branch tips and drastic reduction in fruit yield due to flower and fruit abscission (Syvertsen, 1999). In cases of very fast and severe stress, water stress can cause even more catastrophic events such as xylem embolism and cell dehydration.

Increase in ABA content in plants, especially in the roots, can be related to soil water content (Zhang and Davies, 1987; Gowing et al., 1990; Zhang and Davies, 1990; Gomes et al., 1997; Gomes et al., 2003). When the plants go through a period of water stress, ABA biosynthesis increases in the roots and this is translocated to the shoot via the xylem and can cause stomatal closure (Zhang and Davies, 1987; Gowing et al., 1990; Zhang and Davies, 1990; Parry and Horgan, 1991; Parry et al., 1992; Gomes et al., 1997). Although ABA can also be translocated from the shoot to the roots via the phloem, experiments involving blockage of the phloem vessels demonstrated that the roots are able to synthesize ABA. This hormone in turn influences water conductivity and root growth (Cornish and Zeevaart, 1985).

The relation between $\mathrm{ABA}$ biosynthesis and root dehydration varies among species but the reason for this variation is unknown (Zhang and Tardieu, 1996). It is also not clear how the roots regulate the ABA concentration or the ABA flow in the xylem in response to drought stress (Liang et al. 1997a,b). Tardieu and Davies (1993) developed a model integrating the water relations and chemical signals that control stomatal conductance in plants in dry soil. The authors concluded from the simulations made that the signal from the roots would make the plant to respond to the conditions for water uptake from the soil (water status in the soil and resistance to water flow) on a daily scale while, in the long term, the plant response to this signal would depend on the evaporative demand.

The aim of this work was to verify the relationships between leaf water status of 'Pera' orange trees, submitted to a water stress cycle, $\mathrm{CO}_{2}$ assimilation rates, transpiration and stomatal conductance and leaf ABA content.

\section{MATERIALS AND METHODS}

A field experiment was carried out in April 1999 at the Centro Avançado de Pesquisa Tecnológica do Agronegócio de Citros "Sylvio Moreira", Instituto Agronômico de

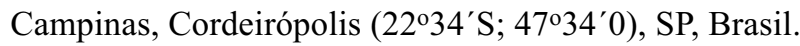

One-year-old 'Pera' orange trees (Citrus sinensis L. Osbeck) grafted onto 'Rangpur' (Citrus limonia Osbeck) lemon rootstocks were transplanted to $100 \mathrm{~L}$ pots containing a mixture of earth, sand and organic matter $(3: 1: 1, \mathrm{v} / \mathrm{v} / \mathrm{v})$ and fitted with an individual drop irrigation system. The plants were kept in a greenhouse, fertilized and sprayed with fungicides and insecticides as needed throughout the experimental period.

Eighteen months after transplanting, the following treatments were applied: irrigated plants and water-stressed plants. Irrigation was withheld by removing the drip system from the pots and no water was given to these plants up to the recovery period. The leaf water potential was measured every day at 2:00 p.m. and when it approached -3.5 MPa in water stressed plants (ten days from the beginning of water stress), the plants were rewatered and measurements were taken for the consecutive ten days.

$\mathrm{CO}_{2}$ assimilation rates $(A)$, stomatal conductance $\left(g_{s}\right)$ and transpiration $(E)$ were measured for leaves of approximately one-year-old plants, using a portable IRGA (infra red gas analyzer, Li 6200, Licor). The measurements were taken around 12:00 a.m. using five leaves for each treatment.

The leaf water potential was measured at 6:00 a.m. ( $\left.\Psi_{p d}\right)$ and 2:00 p.m. $\left(\Psi_{2}\right)$ by a pressure chamber (Plant Moisture Stress, PMS Instruments) with five replicates per treatment. After measuring gas exchanges, three leaves collected per plant from five plants (therefore, 15 leaves) per treatment were immediately placed in liquid nitrogen and stored in an ultra freezer $\left(-80^{\circ} \mathrm{C}\right)$ for posterior quantification of $\mathrm{ABA}$. The leaves were crushed and lyophilised for $72 \mathrm{~h}$, followed by extraction and ABA quantification as described by Norman et al. (1990). ABA was detected by the ELISA immunoassay (enzyme linked-immunosorbent assay kits, Phytodetek). Known ABA concentrations were used in the same immunoassay plate to determine the standard curve. 
All parameters were subjected to an analysis of variance (ANOVA) with five replicates for each treatment. A comparison of means was carried out using Tukey's test at $\mathrm{p} \leq 0.05$.

\section{RESULTS AND DISCUSSION}

The decrease in $A, E$ and $g_{s}$ of irrigated and non-irrigated plants from the first to the fifth day of the experiment (figure 1) was a consequence of climatic alterations such as air temperature, water vapor pressure deficit $(V P D)$ and photosynthetic photon flux density (PPFD) (figure 2). Machado et al. (2002) found that, under natural conditions, $A, E$ and $g_{s}$ varied as a function of temperature and $V P D . A, E$ and $g_{s}$ of the stressed plants were significantly different from control plants on the seventh day of water stress (figures 1A, $1 \mathrm{~B}$ and $1 \mathrm{C})$. From the seventh to the tenth day without irrigation $A, E$ and $g_{S}$ of stressed plants were significantly lower than the values of control plants (figure 1). Although photosynthesis was controlled mainly by stomatal activity, the $\mathrm{CO}_{2}$ assimilation values of the non-irrigated plants could also be affected by non-stomatal factors, such as decreases in the reaction of the photosystems and in the activity of some photosynthetic enzymes, such as ribulose bisphosphate carboxylase/oxygenase (Rubisco), resulting in a reduction of the assimilation of the photosynthetic carbon. In this respect, a reduction in Rubisco concentration was the most striking effect of water stress in the leaves of 'Valencia' orange trees (Vu et al. 1986; Vu and Yelenosky, 1988). The $C_{i}$ increased in stressed plants on the seventh day (figure 3A) while $\mathrm{CO}_{2}$ assimilation decreased as a function of plant dehydration verified by the decline in leaf water potential at 2:00 p.m. The increase in $C_{i}$ when $\Psi_{2}$ is low suggests a decrease in activity of $\mathrm{CO}_{2}$ assimilation mechanisms, with decrease of carboxylation efficiency (Farquhar \& Sharkey, 1982) as shown in figure 3B. The inhibition of net photosynthesis under water stress may result in part from lower diffusion of $\mathrm{CO}_{2}$ across the leaf mesophyll (Flexas and Medrano, 2002). It appears appropriate to refer to $C_{i}$ as the effective $\mathrm{CO}_{2}$ concentration controlling stomata (Mansfield et al., 1990). When there is a plentiful supply of water it is an advantage to have a small response to $C_{i}$, because this reduces the tendency of the stomata to restrict the supply of $\mathrm{CO}_{2}$ for photosynthesis. However, if water supplies are limited, the plant's priority changes from maximizing assimilation to restricting transpiration while maintaining as much assimilation as possible. The decline in the ratio $A / C_{i}$ indicates that nonstomatal factors are acting leading to a decrease of $A$ as the

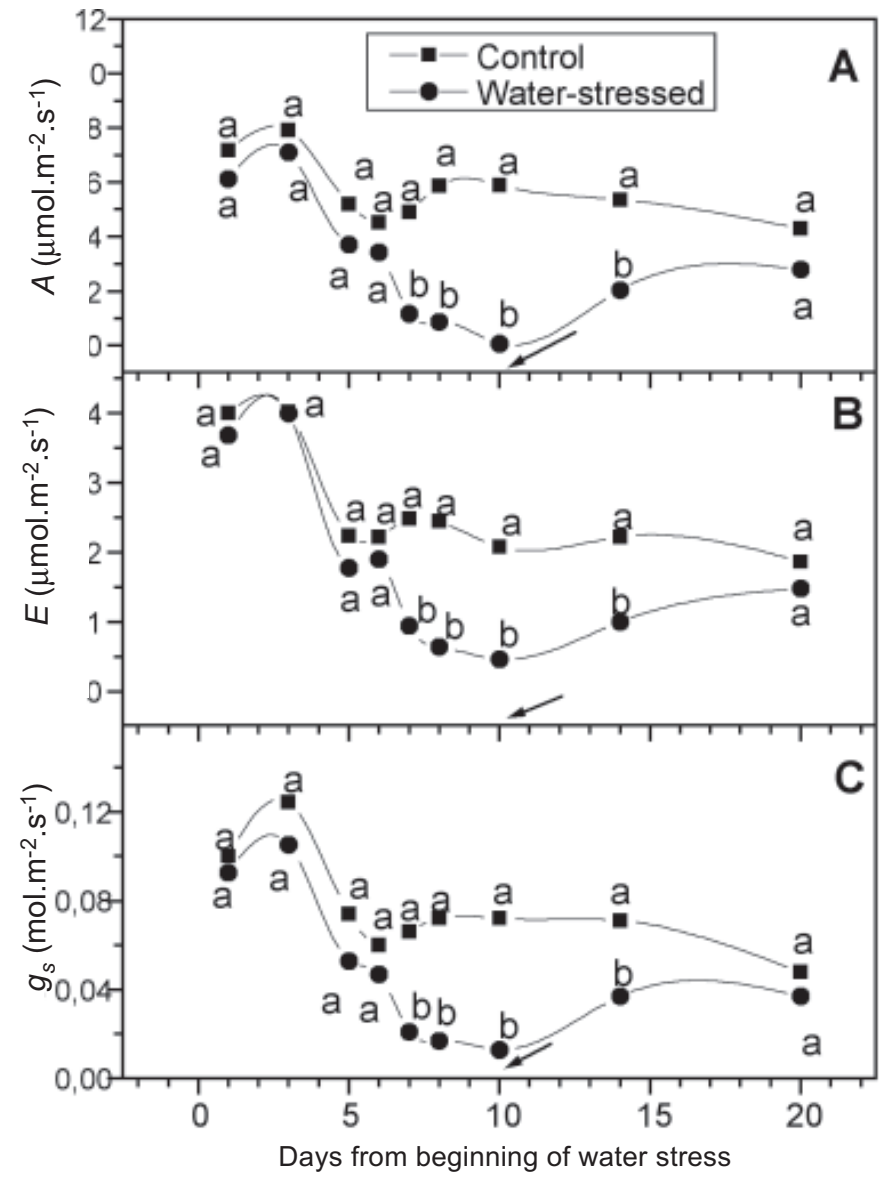

Figure 1. Effects of water stress on $\mathrm{A}) \mathrm{CO}_{2}$ assimilation rate $(A), \mathrm{B})$ transpiration $(E)$ and $\mathrm{C})$ stomatal conductance $\left(\mathrm{g}_{\mathrm{s}}\right)$ of 'Pêra' orange trees. The arrow shows the day of rewatering. Means followed by the same letter are not significantly different. Each point represents the mean of five replicates (Tukey test, 5\%).

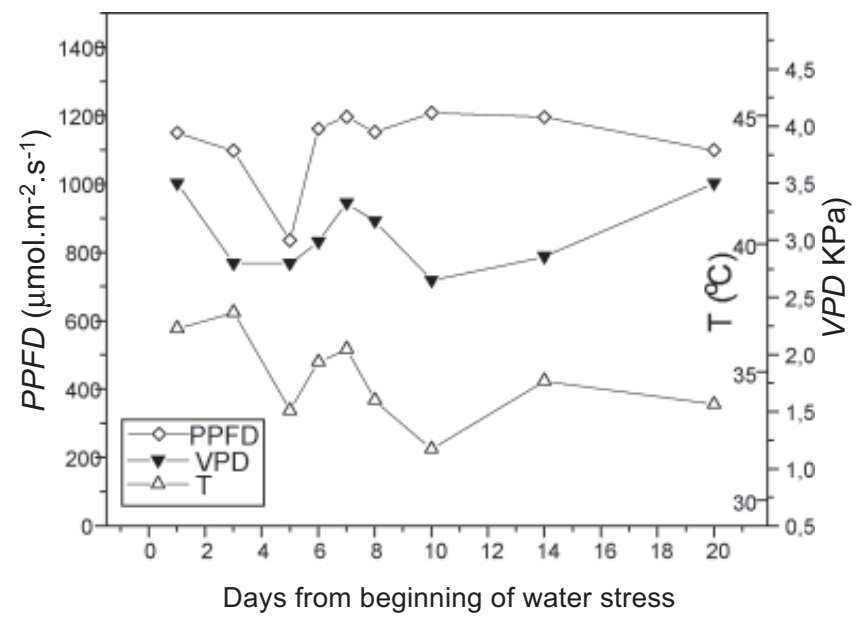

Figure 2. Photosynthetic photon flux density (PPFD), air temperature $(\mathrm{T})$ and vapor pressure deficit between the air and the leaf $(V P D)$ during the measurements days. 


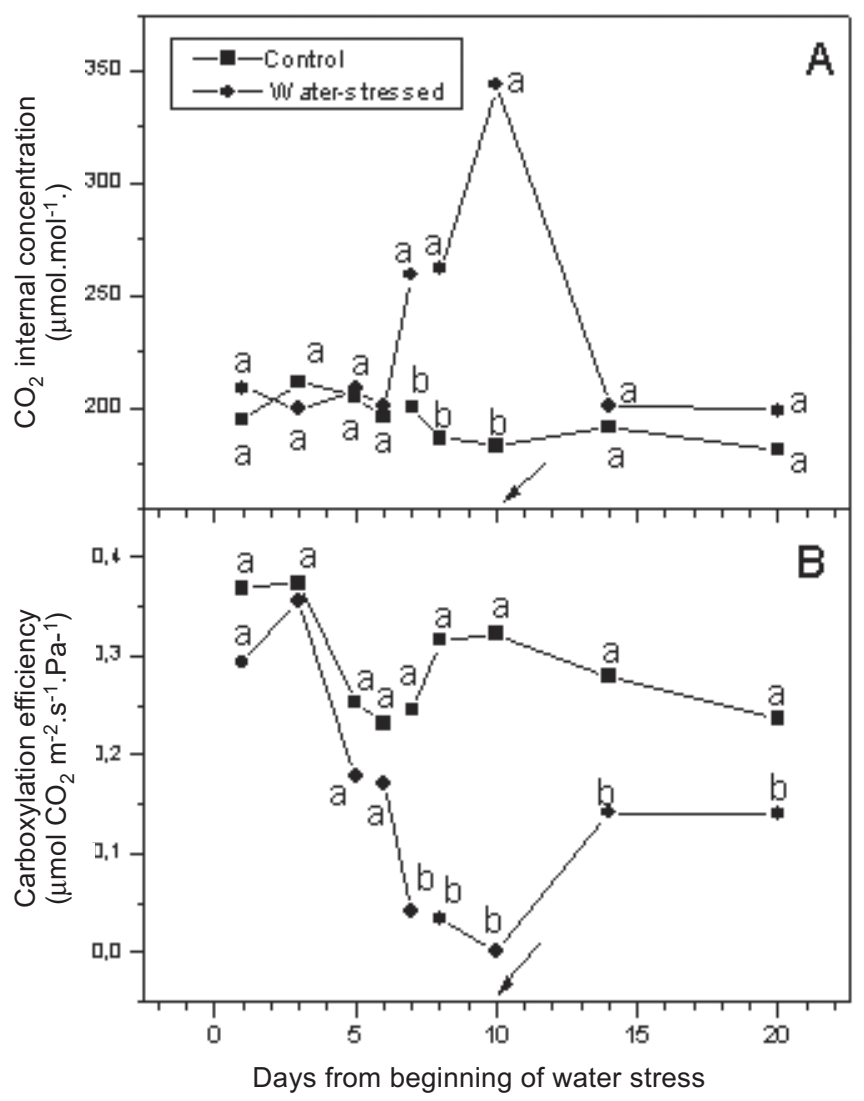

Figures 3. Effects of water stress on $A$ ) $\mathrm{CO}_{2}$ internal concentration $\left(C_{i}\right)$ and $\left.B\right)$ carboxylation efficiency of 'Pêra' orange trees. The arrow shows the day of rewatering. Means followed by the same letter are not significantly different. Each point represents the mean of five replicates (Tukey test, 5\%).

stress becomes more severe after the sixth day without irrigation.

At the end of the tenth day the plants were rewatered and the recovery from stress was evaluated. On the fourth day after rewatering, there were already differences between $A$, $E$ and $\mathrm{g}_{\mathrm{s}}$ among the treatments but by the tenth day there were no statistical differences between the treatments for these parameters (figures 1A, 1B and 1C). Even beyond ten days after plant rewatering, stressed plants still showed lower carboxylation efficiency when compared to non-stressed plants, although $\mathrm{CO}_{2}$ intercellular concentrations of both treatments were not statistically different even after four days of rewatering (figures $3 \mathrm{~A}$ and $3 \mathrm{~B}$ ).

The leaf water potential of both treatments were different on the sixth day of measurements both at 6:00 a.m. $\left(\Psi_{p d}\right)$ and 2:00 p.m. ( $\Psi_{2}$ ) (figures $4 \mathrm{~A}$ and $4 \mathrm{~B}$ ), although photosynthetic activity of the stressed plants had not been affected by the water stress on this day. The lower $\Psi_{p d}$ and $\Psi_{2}$ observed in

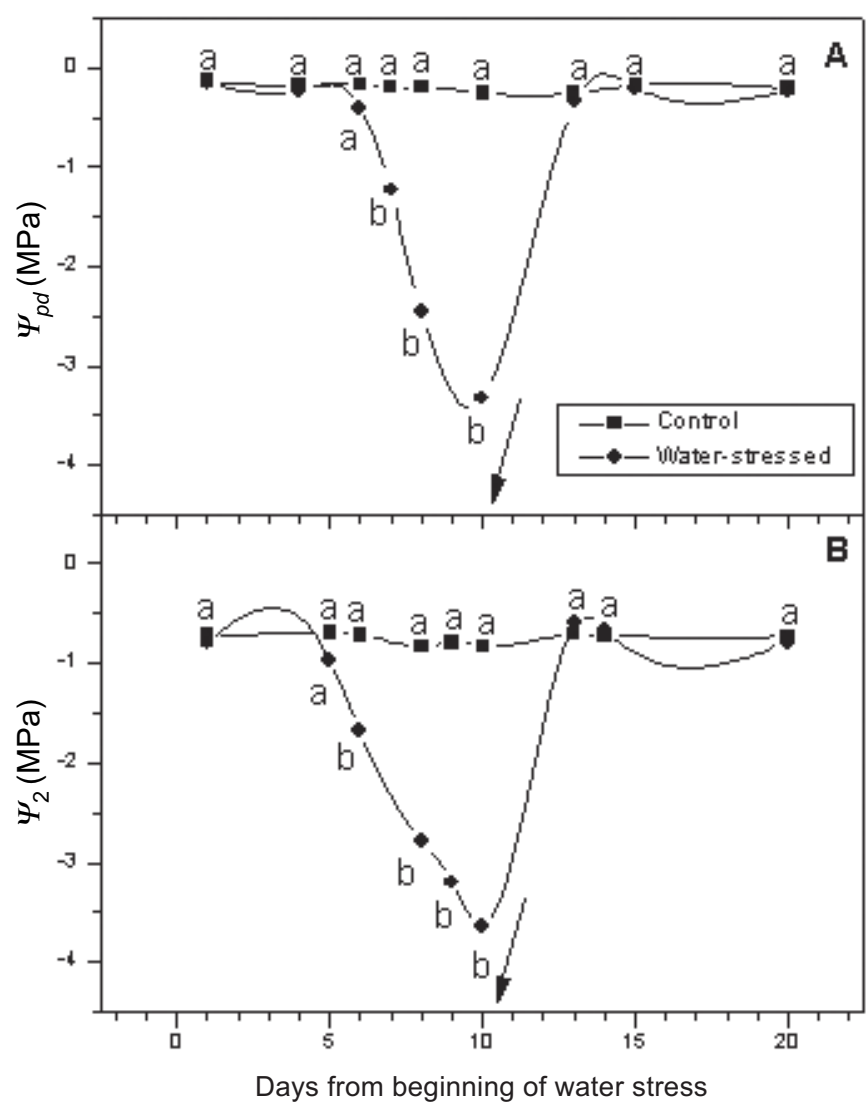

Figure 4. Effects of water stress on A) predawn $\left(\Psi_{p d}\right)$ and B) afternoon leaf water potential $\left(\Psi_{2}\right)$ of 'Pêra' orange trees. The arrow shows the day of rewatering. Means followed by the same letter are not significantly different. Each point represents the mean of five replicates (Tukey test, 5\%).

periods of water stress associated with stomatal closure resulted in decreased transpiration. As the stress became more severe, the leaf water potential decreased, reaching -3.3 and $-3.6 \mathrm{MPa}$ at 6:00 a.m. and 2:00 p.m., respectively (figures $4 \mathrm{~A}$ and $4 \mathrm{~B}$ ) in stressed plants and these plants showed the stomata more closed on the tenth day (figure 1C). Syvertsen (1982) reported that stomatal closure of orange trees under water stress was determined when the $\Psi_{2}$ reached values corresponding to $-2.5 \mathrm{MPa}$ with total stomatal closure occurring with $\Psi_{2}$ at around $-3.0 \mathrm{MPa}$, but $\Psi_{2}$ does not directly modulate the stomatal movement of citrus leaves under well-irrigated conditions.

In this study it was found that when $\Psi_{2}$ varied between 0.5 and $-3.6 \mathrm{MPa}$ in the stressed plants, this was directly related to $g_{s}$ (variation between 0.01 to $0.075 \mathrm{~mol} . \mathrm{m}^{-2} . \mathrm{s}^{-1}$ ) (figure 5). Values of $g_{s}$ between 0.05 and $0.175 \mu \mathrm{mol} . \mathrm{m}^{-2} \cdot \mathrm{s}^{-1}$ could normally be detected in orange trees without large variations in the $\Psi_{2}$. Habermann et al. (2003) found that $g_{s}$, 


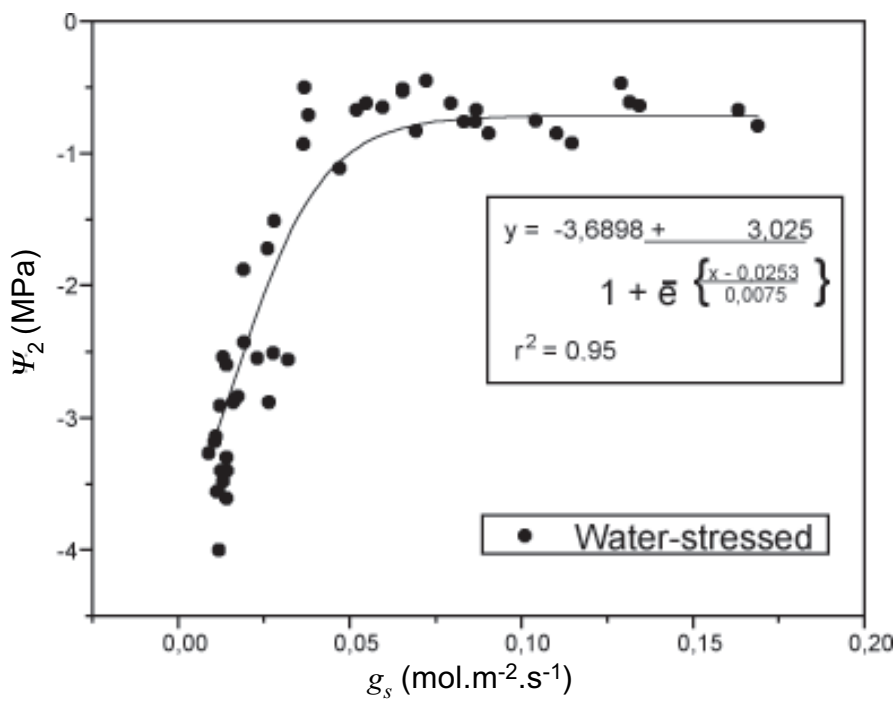

Figure 5. Leaf water potential $\left(\Psi_{2}\right)$ versus stomatal conductance $\left(g_{s}\right)$ of "Pêra" orange trees submitted to water stress. Data obtained from 50 observations.

under controlled conditions, varies with $V P D$, without variations in $\Psi_{2}$, so it is possible that $V P D$ variation is contributing to this variation in $\mathrm{g}_{\mathrm{s}}$. There was a strong correlation $\left(\mathrm{r}^{2}=0.85\right)$ between the $\Psi_{2}$ and the ABA concentration when the stressed plant data were analyzed (figure 6). However, with $\Psi_{2}$ around $-3.6 \mathrm{MPa}$, there is great variation on ABA concentration (figure 6). When plants are irrigated, that is, on the beginning of water stress the $\Psi_{2}$ values are around $-0.5 \mathrm{MPa}$ and the ABA concentration is low. As the leaf water potential decreased as a consequence of substrate drying, ABA concentration increased as a function of its biosynthesis in the roots (Parry \& Horgan, 1991; Parry et al., 1992) with translocation to the shoot, resulting in ABA accumulation in the leaves and stomatal closure. Other studies have shown that stomata can be responsive both to ABA concentration in the xylem and to the flow rate of xylem sap (Gowing et al., 1993; Jarvis and Davies, 1997; Zhang et al., 1997). There was also a strong relationship between $\Psi_{2}$ and stomatal conductance $\left(\mathrm{r}^{2}=0.95\right)$ (figure 5). It was found that at ABA concentrations greater than $1.0 \mu \mathrm{g} . \mathrm{g}^{-1}$ dry matter, the leaf water potential was always less than $-1.0 \mathrm{MPa}$. Likewise when stomatal conductance was less than $0.04 \mu \mathrm{mol} . \mathrm{m}^{-2} . \mathrm{s}^{-1}$, resulting in almost total closure of stomata, $\Psi_{2}$ was less than $-1.0 \mathrm{MPa}$. In the present work it is evident that increases in ABA concentrations were related to stomatal closure when $\Psi_{2}$ was more negative than $-1.0 \mathrm{MPa}$. Tardieu and Davies (1992) reported that water flow in the xylem can dilute the concentration of the signal molecule in the sap but the

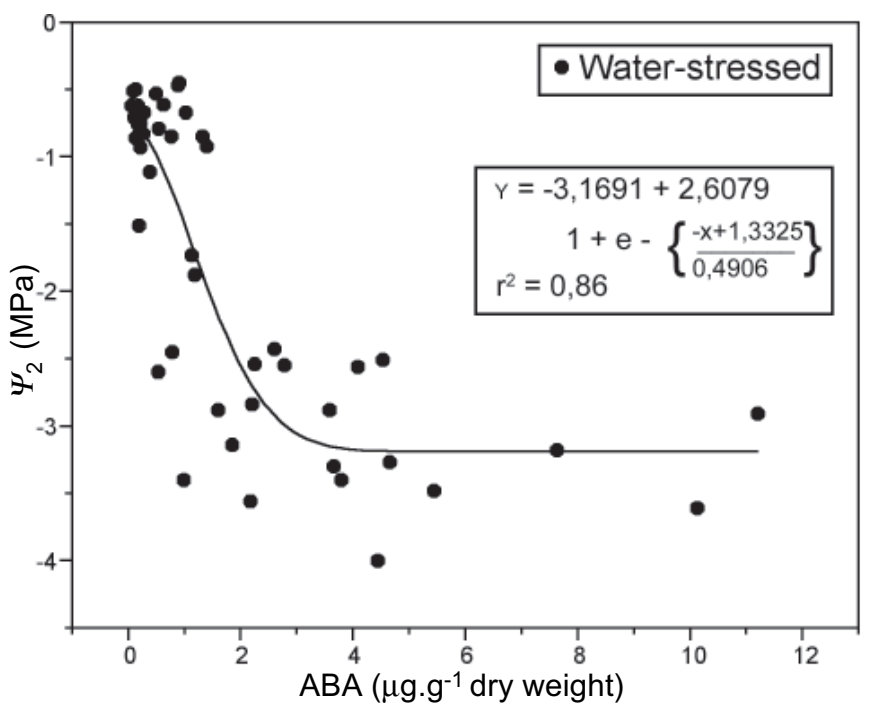

Figure 6. Leaf water potential $\left(\Psi_{2}\right)$ versus abscisic acid contents of "Pêra" orange trees submitted to water stress. Data obtained from 50 observations.

sensitivity of the stomata to this signal is increased as the leaf water potential decreases. Tardieu et al. (1996) reported for several species that stomatal conductance was generally correlated with $\Psi_{2}$ suggesting that chemical signals between the root and shoot are not the only factors involved in stomatal conductance. Correia and Pereira (1995) working with Lupinus albus L. subjected to a moderate water stress detected sufficient ABA accumulation in the xylem to justify the decline in stomatal conductance, but when the water stress became more severe, the correlation between the ABA content and the stomatal conductance could not be established. Socias et al. (1997) did not find coherent relations between stomatal conductance in relation to ABA contents and $\Psi_{2}$ in clover plants under irrigation but Liang and Zhang (1999) reported that the ABA concentration of the xylem and leaves correlated well with stomatal closure in Acacia confusa and Leucaena leucocephala, submitted to water stress. Other authors question whether ABA is solely responsible for stomatal closure as a consequence of soil drying (Munns and King, 1988; Munns, 1992; Munns and Cramer, 1996).

In this study a relationship was established between ABA content, $\Psi_{2}$ and stomatal conductance in orange tree leaves. Water stress in 'Pera' orange trees increased ABA content with consequent stomatal closure and decreased $\Psi_{2}$ values.

Acknowledgements: We are grateful to Fundação de Amparo à Pesquisa do Estado de São Paulo (FAPESP) for financial support. M.M.A.G. is grateful to CAPES and E.C.M. and M.A.M. are grateful to CNPq for fellowships. 


\section{REFERENCES}

Cornish K, Zeevaart JAD (1985) Abscisic acid accumulation by roots of Xanthium strumarium L. and Lycopersicon esculentum Mill. in relation to water stress. Plant Physiol. 79:653-658.

Correia MJ, Pereira JS (1995) The control of leaf conductance of white lupin by xylem ABA concentration decreases with the severity of water deficits. J. Exp. Bot. 46:101-110.

Davies FS, Bower J (1994) Water stress, gas exchange and fruit set of 'Olinda' Valencia orange trees in Eastern Transvaal area of South Africa. Acta. Hort. 365:121-127.

Farquhar GD, Sharkey TD (1982) Stomatal conductance and photosynthesis. Annu. Rev. Plant Physiol. Mol. Biol. 33:317-345.

Flexas J, Medrano H (2002) Drought-inhibition of photosynthesis in $\mathrm{C}_{3}$ plants: stomatal and non-stomatal limitations revisited. Ann. Bot. 898:183-190.

Gomes MMA, Lagôa AMMA, Machado EC, Furlani PR (1997) Gas exchange and abscisic acid quantification in two upland rice cultivars submitted to water deficiency. Braz. J. Plant Physiol. 9(3):177-183.

Gomes MMA, Lagôa AMMA, Machado EC, Medina CL (2003) Abscisic acid and indole 3-acetic acid contents in orange trees infected by Xylella fastidiosa and submitted to cycles of water stress. Plant Growth Regul. 39(3):263-270.

Gowing DJG, Davies WJ, Jones HG (1990) A positive rootsourced signal as an indicator of soil drying in apple, Malus x domestica Borkh. J. Exp. Bot. 41:1535-1540.

Gowing DJG, Jones HG, Davies WJ (1993) Xylem transported abscisic acid: the relative importance of its mass and its concentration in the control of stomatal aperture. Plant Cell Environ. 16:453-459.

Habermann G, Machado EC, Rodrigues JD, Medina CL (2003) Gas exchange rates at different vapor pressure deficits and water relations of 'Pera' sweet orange plants with citrus variegated chlorosis (CVC). Sci. Hort. 98:233-245.

Jarvis AJ, Davies WJ (1997) Whole-plant ABA flux and the regulation of water loss in Cedrella odorata. Plant Cell Environ. 20:521-527.

Liang J, Zhang J (1999) The relations of stomatal closure and reopening to xylem ABA concentration and leaf water potential during soil drying and rewatering. Plant Growth Regul. 29:77-86.

Liang J, Zhang J, Wong MH (1997a) How do roots control xylem sap ABA concentration in response to soil drying? Plant Cell Physiol. 38:10-16.

Liang J, Zhang J, Wong MH (1997b) Can stomatal closure caused by xylem ABA explain the inhibition of leaf photosynthesis under soil drying? Photosynth. Res. 51:149159.

Machado EC, Medina CL, Gomes MMA (1999). Substrate water content and photosynthesis in "Valencia" orange trees. Bragantia 58: 217-226.

Machado EC, Medina CL, Gomes MMA, Habermann G (2002) Seasonal variation of photosynthetic rates, stomatal conductance and leaf water potential in 'Valencia' orange trees. Sci. Agricola 59:53-58.
Mansfield TA, Hetherington AM, Atkinson CJ (1990) Some current aspects of stomatal physiology. Annu. Rev. Plant Physiol. Plant Mol. Biol. 41:55-75.

Marler TE, Davies FS (1988) Soil water content and leaf gas exchange of young, field grown 'Hamlin' orange trees. Proceed. Int. Am. Soc. Hort. 32:51-64.

Medina CL, Machado EC, Gomes MMA (1999) Stomatal conductance, transpiration and photosynthesis rates in "Valencia" orange trees submitted to water stress. Braz. J. Plant Physiol. 11:29-34.

Medina CL, Machado EC (1998) Gas exchange and water relations of 'Valencia' orange tree grafted on 'Rangpur' lime and Poncirus trifoliata, submitted to a water deficit. Bragantia 57:15-22.

Medina CL, Machado EC, Pinto JM (1998) Photosynthesis of 'Valencia' orange tree grafted on four rootstocks and submitted to water deficit. Bragantia, 57:1-14.

Munns R, King RW (1988) Abscisic acid is not the only stomatal inhibitor in the transpiration stream of wheat plants. Plant Physiol. 88:703-708.

Munns R (1992) A leaf elongation assay detects an unknown inhibitor in xylem sap from wheat and barley. Aust. J. Plant Physiol. 19:127-135.

Munns R, Cramer GR (1996) Is coordination of leaf and root growth mediated by abscisic acid? Opinion Plant Soil 185:33-49.

Norman SM, Maier VP, Pon DL (1990) Abscisic acid accumulation and carotenoid and chlorophyll content in relation to water stress and leaf age of different types of citrus. J. Agric. Food Chem. 38:1326-1334.

Ortuño MF, Alarcón JJ, Nicolás E, Torrecillas A (2004) Interpreting trunk diameter in young lemon trees under deficit irrigation. Plant Sci. 167:275-280.

Parry AD, Horgan R (1991) Abscisic acid biosynthesis in roots. I The identification of potential abscisic acid precursors and other carotenoids. Planta 187:185-191.

Parry AD, Griffiths A, Horgan R (1992) Abscisic acid biosynthesis in roots. II The effects of water stress in wild type and abscisic acid deficient mutant (notabilis) plants of Lycopersicon esculentum Mill. Planta 187:192-197.

Socias X, Correia MJ, Chaves MM, Medrano H (1997) The role of abscisic acid and water relations in drought responses of subterranean clover. J. Exp. Bot. 48:1281-1288.

Syvertsen JP (1982) Minimum leaf water potential and stomatal closure in citrus leaves of different ages. Ann. Bot. 47:827-834.

Syvertsen JP (1999) Physiological determinants of citrus tree growth and development. In: Rodrigues JD (ed), Proceedings of the First International Symposium of Fruit Crop- Production and Quality of Citrus Fruits. Unesp, Botucatu, pp. 123-160.

Tardieu F, Davies WJ (1992) Stomatal response to abscisic acid is a function of current plant water status. Plant Physiol. 98:540-545.

Tardieu F, Davies WJ (1993) Integration of hydraulic and chemical signaling in the control of stomatal conductance and water status of droughted plants. Plant Cell Environ. $16: 341-349$. 
Tardieu F, Lafarge T, Simonneau T (1996) Stomatal control by fed or endogenous xylem ABA in sunflower: interpretation of correlations between leaf water potential and stomatal conductance in anisohydric species. Plant Cell Environ. 19:75-84.

Vu JCV, Yelenosky G, Bausher MG (1986) $\mathrm{CO}_{2}$ exchange rate, stomatal conductance and transpiration in attached leaves of 'Valencia' orange. Hortic. Sci. 21(1):143-144.

Vu JCV, Yelenosky G (1988) Solar irradiance and drought stress effects on the activity and concentration of ribulose bisphosphate carboxylases in 'Valencia' orange leaves. Israel J. Bot. 37:245-256.
Zhang J, Davies WJ (1987) Increased synthesis of ABA in partially dehydrated root tips and ABA transport from roots to leaves. J. Exp. Bot. 38:2015-2023.

Zhang J, Davies WJ (1990) Changes in the concentration of ABA in xylem sap as a function of changing soil water status can account for changes in leaf conductance and growth. Plant Cell Environ. 13:277-285.

Zhang J, Tardieu F (1996) Relative contribution of apices and mature tissues to ABA synthesis in droughted maize root systems. Plant Cell Physiol. 37(5):598-605.

Zhang J, Jia W, Zhang D-P (1997) Re-export and metabolism of xylem-delivered ABA in attached maize leaves under different transpirational fluxes and xylem ABA concentrations. J. Exp. Bot. 48:1557-1564. 